\title{
MAGNESIUM IN THE DYNAMICS OF CARBOHYDRATES AND ANTIOXIDANT METABOLISM OF COFFEE SEEDLINGS IN TWO IRRADIANCE LEVELS
}

\author{
Kaio Gonçalves de Lima Dias ${ }^{1}$, Paulo Tácito Gontijo Guimarães², Antônio Eduardo Furtini Neto³, \\ Valdemar Faquin ${ }^{4}$, Eduane José de Pádua ${ }^{5}$, Helbert Rezende Oliveira de Silveira ${ }^{6}$
}

(Received: May 28, 2018; accepted: July 16, 2018)

\begin{abstract}
The aim of this study was to verify the physiological impacts and the carbohydrate dynamics of Coffea arabica, seedlings subjected to increasing concentrations of magnesium $(\mathrm{Mg})$ and two irradiance levels. Methods: The experiment was carried out in growth chambers with nutrient solution. The treatments were five concentrations of $\operatorname{Mg}(0,48,96,192$, and $\left.384 \mathrm{mg} \mathrm{L}^{-1}\right)$ and two irradiance levels $\left(80\right.$ and $320 \mu \mathrm{mol}$ of photons $\left.\mathrm{m}^{-2} \mathrm{~s}^{-1}\right)$. The coffee seedlings were under the treatments for 90 days. Results: The leaves with deficiency or excess of $\mathrm{Mg}$ exposed to the irradiance of $320 \mu \mathrm{mol}$ of photons $\mathrm{m}^{-2} \mathrm{~s}^{-1}$ accumulated more carbohydrates than those exposed to $80 \mu \mathrm{mol}$ of photons $\mathrm{m}^{-2} \mathrm{~s}^{-1}$. The accumulation of carbohydrates in the leaves increased the activity of antioxidant enzymes due to the increased production of reactive oxygen species (ROS). Leaves exposed to $320 \mu \mathrm{mol}$ of photons $\mathrm{m}^{-2} \mathrm{~s}^{-1}$ exhibited symptoms of scald by the sun caused by photo-oxidation. The scald was more intense in plants with abnormal concentrations of $\mathrm{Mg}$. The antioxidant system of the coffee tree is closely relates to the $\mathrm{Mg}$ supply and irradiance levels. Concentrations of $\mathrm{Mg}$ between 48 and $96 \mathrm{mg} \mathrm{L}^{-1}$ functioned as a mitigating agent of oxidative stress under stressful conditions caused by high irradiance level.
\end{abstract}

Index terms: Oxidative stress, enzyme activity, scald, coffee nutrition.

\section{MAGNÉSIO NA DINÂMICA DE CARBOIDRATOS E NO METABOLISMO ANTIOXIDANTE DE CAFEEIROS SUBMETIDOS A DOIS NÍVEIS DE IRRADIÂNCIA}

RESUMO: O objetivo deste trabalho foi verificar os impactos fisiológicos e a dinâmica de carboidratos em mudas de Coffea arabica. cultivadas em solução nutritiva, com doses crescentes de magnésio (Mg) sob o efeito de dois níveis de irradiância. O experimento foi conduzido em câmaras de crescimento com mudas de café da cultivar Mundo Novo IAC 379/19. Os

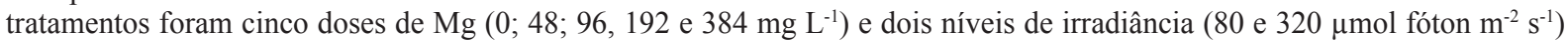
aos quais as mudas foram expostas, em delineamento em blocos casualizados, em arranjo fatorial 5x2, com 6 repetições, e uma planta por unidade experimental $(\mathrm{n}=60)$. As plantas supridas com concentrações de $\mathrm{Mg}$ menores ou maiores do que a recomendada para a cultura $\left(48 \mathrm{mg} \mathrm{L}^{-1}\right)$ expostas à irradiância de $320 \mu \mathrm{mol}$ de fótons $\mathrm{m}^{-2} \mathrm{~s}^{-1}$ acumularam mais carboidratos do que as expostas a $80 \mu \mathrm{mol}$ de fótons $\mathrm{m}^{-2} \mathrm{~s}^{-1}$. A acumulação de carboidratos nas folhas aumentou a atividade de enzimas antioxidantes devido ao aumento da produção de espécies reativas de oxigênio. As folhas expostas a $320 \mu \mathrm{mol}$ de fótons $\mathrm{m}^{-2}$ $\mathrm{s}^{-1}$ apresentaram sintomas de escaldadura de sol causada por foto-oxidação. A escaldadura foi mais intensa em plantas com concentrações anormais de $\mathrm{Mg}$. O sistema antioxidante das mudas de café está intimamente relacionado às concentrações de $\mathrm{Mg}$ nas folhas. As concentrações de $\mathrm{Mg}$ entre 48 e $96 \mathrm{mg} \mathrm{L}^{-1}$ funcionaram como agente atenuante do estresse oxidativo em condições estressantes de alto nível de irradiância.

Termos para indexação: Estresse oxidativo, atividade enzimática, escaldadura, nutrição do cafeeiro.

\section{INTRODUCTION}

Magnesium $(\mathrm{Mg})$ is an important nutrient for plants because compose the chlorophyll molecules, which contribute to the energy metabolism of the plants (photosynthesis). Consequently, $\mathrm{Mg}$ deficiency affects many biochemical and physiological processes that decreasing the growth and yield of crops (CAKMAK; YAZICI, 2010).

Magnesium has a primary role in the transport of carbohydrates, especially sucrose. The accumulation of carbohydrates in leaves seems to be one of the first symptoms of $\mathrm{Mg}$ deficiency (SILVA et al., 2014). This elevated concentration of carbohydrates in leaves of plants deficient in $\mathrm{Mg}$, accompanied by an increase in the ratio of the mass of the aerial part by the root is indicative of severe inhibition in the export of photoassimilates (sugars) in the phloem (CAKMAK; KIRKBY, 2008; CAKMAK; YAZICI, 2010). The reduction of transportation of carbohydrates and, consequently, the growth of the roots, decrease the water and nutrients absorption and thus decreasing the productivity of the crops.

\footnotetext{
1,2Empresa de Pesquisa Agropecuária de Minas Gerais/EPAMIG - Cx. P. 176 - 37.200-000 - Lavras-MG - kaiogld@gmail.com, paulotgg@epamig.ufla.br

${ }^{3}$ Instituto Tecnológico Vale Desenvolvimento Sustentável - 66.055-090 - Belém - PA - furtinineto@gmail.com

${ }^{4,5}$ Universidade Federal de Lavras/UFLA - Departamento de Ciência do Solo/DCS - Cx. P. 3037 - 37.200-000 - Lavras - MG eduanepadua@hotmail.com,vafaquin@dcs.ufla.br

${ }^{6}$ Centro Universitário Presidente Tancredo de Almeida Neves - Avenida Leite de Castro, 1101 - Fábricas - 36.301-182

São João Del Rei - MG - herosrezende@yahoo.com.br
}

Coffee Science, Lavras, v. 13, n. 3, p. 365 - 378, jul./sep. 2018 
Additionally, the accumulation of carbohydrates in the leaves could stimulate the production of reactive oxygen species (ROS) which are toxic to plant species (MARSCHNER, 2012).

The irradiance levels also influence the biochemical and physiological processes in the plants, influencing severely the transport of carbohydrates and the growth of roots. Typical visual symptoms of $\mathrm{Mg}$ deficiency are clearly note at high irradiance level (CAKMAK; KIRKBY, 2008).

The antioxidant skill of plants is considers an important factor in their protection against different environmental stresses (GILL; TUTEJA, 2010). The fundamental difference between the sensitive plants and those resilient to oxidative stress is the capability to reduce the damage caused by free radicals produced during the environmental stress (SÁNCHEZ-RODRIQUEZ et al., 2010).

Different stresses suffered by plants increase the production of ROS, for example, superoxide, hydrogen peroxide, and hydroxyl radicals that become harmful to the plant's organism when their production is higher than the antioxidant agent's production, thus resulting in oxidative stress (HUSSAIN et al., 2011).

An efficient degradation of ROS requires the joint action of enzymes of the antioxidant system of the plants - mainly superoxide dismutase (SOD), catalase (CAT), and ascorbate peroxidase (APX) (NEILL et al., 2008). Despite the presence of an effective antioxidant system, oxidative damage still occurs in the plant cells due to either the uncontrolled production or inefficient removal of ROS.

The climate change, especially in the last decade, may modify the areas of expansion of agriculture, and it could influence the plant's growth, mainly in areas like Brazilian Cerrado, where plants would have to grow under a much higher irradiance than the light saturation point of the photosynthetic apparatus. Thus, a detailed study of $\mathrm{Mg}$ nutrition in coffee as a function of irradiance is required.

Therefore, the objective in this work was to determine the physiological impacts and carbohydrate dynamics in Coffea arabica L. seedlings with increasing concentrations of $\mathrm{Mg}$ and different irradiance levels.

\section{MATERIAL AND METHODS}

The experiment was carried out in growth chambers, under controlled conditions and with nutrient solution by Hoagland and Arnon (1950).
The treatments were five concentrations of $\mathrm{Mg}(0$, $48,96,192$, and $384 \mathrm{mg} \mathrm{L}^{-1}$ ) and two irradiance levels (80 and $320 \mu \mathrm{mol}$ of photons $\mathrm{m}^{-2} \mathrm{~s}^{-1}$ ); the standard concentration of $\mathrm{Mg}$ is $48 \mathrm{mg} \mathrm{L}^{-1}$ (HOAGLAND; ARNON, 1950), and the irradiance level of $80 \mu \mathrm{mol}$ of photons $\mathrm{m}^{-2} \mathrm{~s}^{-1}$ simulating the conditions of low incident radiation, such as in shaded coffee trees within the plant canopy or in coffee trees in high-density plantations, whereas $320 \mu \mathrm{mol}$ of photons $\mathrm{m}^{-2} \mathrm{~s}^{-1}$ simulated normal conditions of photosynthetic activity.

Six repetitions of three-liter pots were used as growth chambers, with one coffee seedling per growth chamber, organized in randomized blocks of a 5 X 2 factorial arrangement $(n=60)$.

Coffee seedlings of Mundo Novo IAC $379 / 19$ cultivar with four pairs of true leaves cultivated in substrate not limed were transfer to trays containing deionized water for 10 days until the growth of new roots. The plants were transfer to three-liter pots containing $50 \%$ ionic strength of the Hoagland and Arnon (1950) solution, but excluding $\mathrm{Mg}$, where they remained under constant aeration for 15 days.

After this period, the nutrient solution was replaced by $100 \%$ ionic strength of the Hoagland and Arnon (1950) solution and $\mathrm{Mg}$ was added at the concentrations of $0,48,96,192$, and $384 \mathrm{mg} \mathrm{L}^{-1}$. The volume of the pots were fill with deionized water daily, $\mathrm{pH}$ was adjusted to $5.0-5.5$ by addition of $\mathrm{HCl} 0.1 \mathrm{~mol} \mathrm{~L}^{-1}$ or $\mathrm{NaOH} 0.1 \mathrm{~mol} \mathrm{~L}^{-1}$, and the pots were kept aerated continually.

The lighting was provides by special daylight tubular fluorescent bulbs (Osram 20W). The levels of irradiance were controlled using shelves to regulate the distance between the plants and the light source. The irradiance levels at the different heights were measured using a quantum sensor (Licor LI-190SA, Li-Cor Biosciences Inc., Lincoln, USA). The plants were subjected to a photoperiod of $12 \mathrm{~h}$ of light and $12 \mathrm{~h}$ of darkness simulating a natural condition of tropical regions.

Fully expanded leaves were collected ninety days after the application of the treatments to performing the physiological analyses. After the material was collects, it was immediately preserved in liquid nitrogen and then stored at $-80^{\circ} \mathrm{C}$ in a deep freezer. Subsequently, the plants were exposed to full sun for three days, in an irradiance of $1500 \mu \mathrm{mol}$ of photons $\mathrm{m}^{-2} \mathrm{~s}^{-1}$ and one more fully expanded leaf was sampled for the physiological analyses. The plants were then harvest and divided into leaves, stems and roots that were wash in deionized water, packed in paper bags, and dried at $60{ }^{\circ} \mathrm{C}$ until constant weights. 
The dried leaves, stems, and roots were milled and a portion of the dry-milled material was sample for nutritional analysis following EMBRAPA (2009). Samples of dry-milled leaves were take for carbohydrate analysis.

\subsection{Carbohydrates}

The carbohydrates were extract from $25 \mathrm{mg}$ of the dry mass of leaves, homogenized in $100 \mathrm{mM}$ potassium phosphate buffer, $\mathrm{pH}$ 7.0, followed by a water bath at $40{ }^{\circ} \mathrm{C}$ for $30 \mathrm{~min}$ (ZANANDREA et al., 2010). Subsequently, $1.0 \mathrm{~mL}$ of water was extracts through ultrasonication at $60{ }^{\circ} \mathrm{C}$ for 15 min. An aliquot of $500 \mu \mathrm{L}$ was transfers to 1.5 $\mathrm{mL}$ tube and centrifuged at $5,500 \mathrm{rpm}$ for $5 \mathrm{~min}$. The supernatant was diluted and filtered through a PES membrane with $0.22 \mu \mathrm{m}$ pores (adapted from MELLINGER, 2006).

The following standards were use: for glucose and galactose analysis - Sigma-Aldrich (St. Louis, MO, USA); for sucrose and fructose analysis - Fluka (St. Louis, MO, USA). The mobile phase was prepared from $50-52 \% \mathrm{NaOH}$ solution sourced from Sigma-Aldrich (St. Louis, MO, USA). All solutions were prepared using water obtained from a Milli-Q Biocel system from Millipore (Billerica, MA, USA).

The samples were analysed using an HPLC system (Shimadzu, Kyoto, Japan) coupled to an Antec DECADE II detector (Zoeterwoude, Netherlands) - the electrochemical cell was equipped with a gold electrode. The HPLC system, controlled by CBM-20A and with PEEK piping, was set to the isocratic flow of the $20 \mathrm{mM}$ $\mathrm{NaOH}$ solution - which had been previously degassed in DGU-A $\mathrm{A}_{5}$ - supplied at $0.2 \mathrm{ml} \cdot \mathrm{min}^{-1}$ by an LC-10Ai pump. A volume of $20 \mu \mathrm{L}$ of the samples was injects (model 7725i Rheodyne injector) - the separation was performed by a $250 \times 4 \mathrm{~mm}$ internal diameter DIONEX CarboPac PA1 column (Sunnyvale, CA) equipped with precolumn and maintained at $44{ }^{\circ} \mathrm{C}$. The saccharides were analysed by pulsed amperometric detection, with the following detection conditions: $\mathrm{E}_{1}=$ $+0.05 \mathrm{~V}, \mathrm{t}_{1}=500 \mathrm{~ms}$, and $\mathrm{t}_{\mathrm{s}}=60 \mathrm{~ms} ; \mathrm{E}_{2}=+0.75 \mathrm{~V}$ and $\mathrm{t}_{2}=130 \mathrm{~ms}$; and $\mathrm{E}_{3}=-0.80 \mathrm{~V}$ and $\mathrm{t}_{3}=120 \mathrm{~ms}$ (MARTINS et al., 2005).

The total soluble sugar (TSS) content was calculates by summing the sucrose, fructose, glucose, and galactose contents.

\subsection{Antioxidant enzymes}

The enzyme extract was obtained through the maceration in liquid nitrogen of $0.1 \mathrm{~g}$ of leaves, to which was added $1.5 \mathrm{ml}$ of the extraction buffer containing $1.47 \mathrm{ml}$ of $0.1 \mathrm{M}$ potassium phosphate buffer (pH 7.0), $15 \mu \mathrm{L}$ of 0.1 M EDTA ( $\mathrm{pH} 7.0$ ), $6 \mu \mathrm{L}$ of $0.5 \mathrm{M}$ DTT, $12 \mu \mathrm{L}$ of $0.1 \mathrm{M}$ PMSF, 0.001 $\mathrm{M}$ ascorbic acid, and $22 \mathrm{mg}$ of PVPP. The extract was centrifuged at $12,000 \mathrm{~g}$ for $10 \mathrm{~min}$ at $4{ }^{\circ} \mathrm{C}$, and the supernatant was collected, stored at -20 ${ }^{\circ} \mathrm{C}$ and used in the following enzymatic analyses: catalase (CAT), superoxide dismutase (SOD) and ascorbate peroxidase (APX) (BIEMELT et al., 1998).

a) Catalase

CAT activity was evaluated using a $5 \mu \mathrm{L}$ aliquot of the enzyme extract, which was added to $950 \mu \mathrm{L}$ of the incubation medium containing $200 \mathrm{mM}$ potassium phosphate $(\mathrm{pH} \mathrm{7.0)}$ and 12.5 $\mathrm{mM} \mathrm{H} \mathrm{H}_{2}$ and incubated at $28{ }^{\circ} \mathrm{C}$. The activity was determines by the decrease in the absorbance at $240 \mathrm{~nm}$ every 15 seconds for $3 \mathrm{~min}$, monitored by the consumption of the hydrogen peroxide (HAVIR; MCHALE, 1987).

b) Superoxide dismutase

SOD activity was evaluated by the ability of the enzyme to inhibit the photoreduction of nitroblue tetrazolium (NBT) (MAROUANE et al., 2011) in an incubation medium consisting of $50 \mathrm{mM}$ potassium phosphate at $\mathrm{pH} 7.8,14 \mathrm{mM}$ methionine, $0.1 \mu \mathrm{M}$ EDTA, $75 \mu \mathrm{M}$ NBT, and 2 $\mu \mathrm{M}$ riboflavin. The tubes with the reaction medium and the sample were illuminate for 7 min using a $20 \mathrm{~W}$ fluorescent lamp. The same reaction medium without the sample was illuminates for the control and the blank was kept in the dark. The readings were taken at $560 \mathrm{~nm}$, and the concentration of SOD was calculated using the following equation:

One unit of SOD corresponds to the amount of enzyme capable of inhibiting the photoreduction of NBT by $50 \%$ under the assay conditions.

c) Ascorbate peroxidase

APX activity was determined by monitoring the oxidation rate of the ascorbate at $290 \mathrm{~nm}$ every $15 \mathrm{~s}$ for $3 \mathrm{~min}$. An aliquot of 5 $\mu \mathrm{L}$ of the enzyme extract was added to $950 \mu \mathrm{L}$ of incubation buffer consisting of $500 \mu \mathrm{L}$ of 200 $\mathrm{mM}$ potassium phosphate $(\mathrm{pH} 7.0), 50 \mu \mathrm{L}$ of 10 $\mathrm{mM}$ ascorbic acid, and $50 \mu \mathrm{L}$ of $2 \mathrm{mM}$ hydrogen peroxide (NAKANO; ASADA, 1981). The molar extinction coefficient used was $2.8 \mathrm{mM}^{-1} \mathrm{~cm}^{-1}$. 


\subsection{Statistical analyses}

Regression equations were estimate for the Mg concentrations. Mean tests (Scott-Knott) were complete to examine the differences in the irradiance levels at each $\mathrm{Mg}$ concentration. All analyses were performed using the Sisvar software (Ferreira, 2011), and graphs were built using the SigmaPlot 11.0 software. The maximum and minimum points of the quadratic functions were get through making the first order derivative equal to zero.

\section{RESULTS AND DISCUSSION}

\subsection{Nutrient content}

The content of $\mathrm{Mg}$ in leaves increased while $\mathrm{K}$ in leaves decreased with the concentration of $\mathrm{Mg}$ applied (Figure 1), fitted by quadratic functions for both irradiance levels. This reduction in the $\mathrm{K}$ leaf contents is due to the antagonistic effect of these nutrients (Figure 1b). In general, increasing the amount absorbed from one cation can result in the reduction of the absorption of another cation (MARSCHNER, 2012).

\subsection{Carbohydrate content}

The levels of sucrose, reducing sugars fructose, glucose, and galactose and total soluble sugars (TSS) were significantly influence by the concentrations of magnesium $(\mathrm{Mg})$ and by the applied irradiance levels, as well as by the interactions between these factors (Figure 2). The interaction between the $\mathrm{Mg}$ concentrations and the irradiance levels was significant for sucrose (Figure 2A), fructose (Figure 2B), glucose (Figure 2C), galactose (Figure 2D), and TSS (Figure 2E).

The leaves of coffee seedlings with $0 \mathrm{mg}$ of $\mathrm{Mg} \mathrm{L}^{-1}$ (control) showed sucrose accumulation (Figure 2A). One of the first symptoms of $\mathrm{Mg}$ deficiency is the accumulation of sucrose (HERMANS et al., 2010; SILVA et al., 2014). The accumulation of sucrose in the leaves of plants deficient in $\mathrm{Mg}$ is related to the reduction in its transport to the roots via phloem, which causes a drastic reduction in root growth (CAKMAK et al., 1994; CAKMAK; YAZICI, 2010; HERMANS et al., 2010; SILVA et al., 2014) and decreasing absorption of water and nutrients, thus hampering the growth and productivity of the coffee plants.

Sucrose contents decreased with increasing concentrations of $\mathrm{Mg}$ up to 96 and $48 \mathrm{mg} \mathrm{L}^{-1}$ for irradiance levels of 80 and $320 \mu \mathrm{mol}$ of photons $\mathrm{m}^{-2} \mathrm{~s}^{-1}$, respectively. The influence of the reduction in photosynthesis on the slower transport of sucrose via the phloem is questionable because the decrease in the photosynthesis rate occurs in stages following $\mathrm{Mg}$ deficiency (CAKMAK; KIRKBY, 2008). Accumulation of carbohydrates in the leaves in low Mg content seems to result in adverse effects on photosynthetic gene activity, such as the gene responsible for the coding of chlorophylls $a$ and $b$ (HERMANS et al., 2010) which is partially responsible for the decline in both the chlorophyll contents and the photochemical performance in more advanced stages of Mg deficiency (CAKMAK et al., 1994; HERMANS et al., 2010).
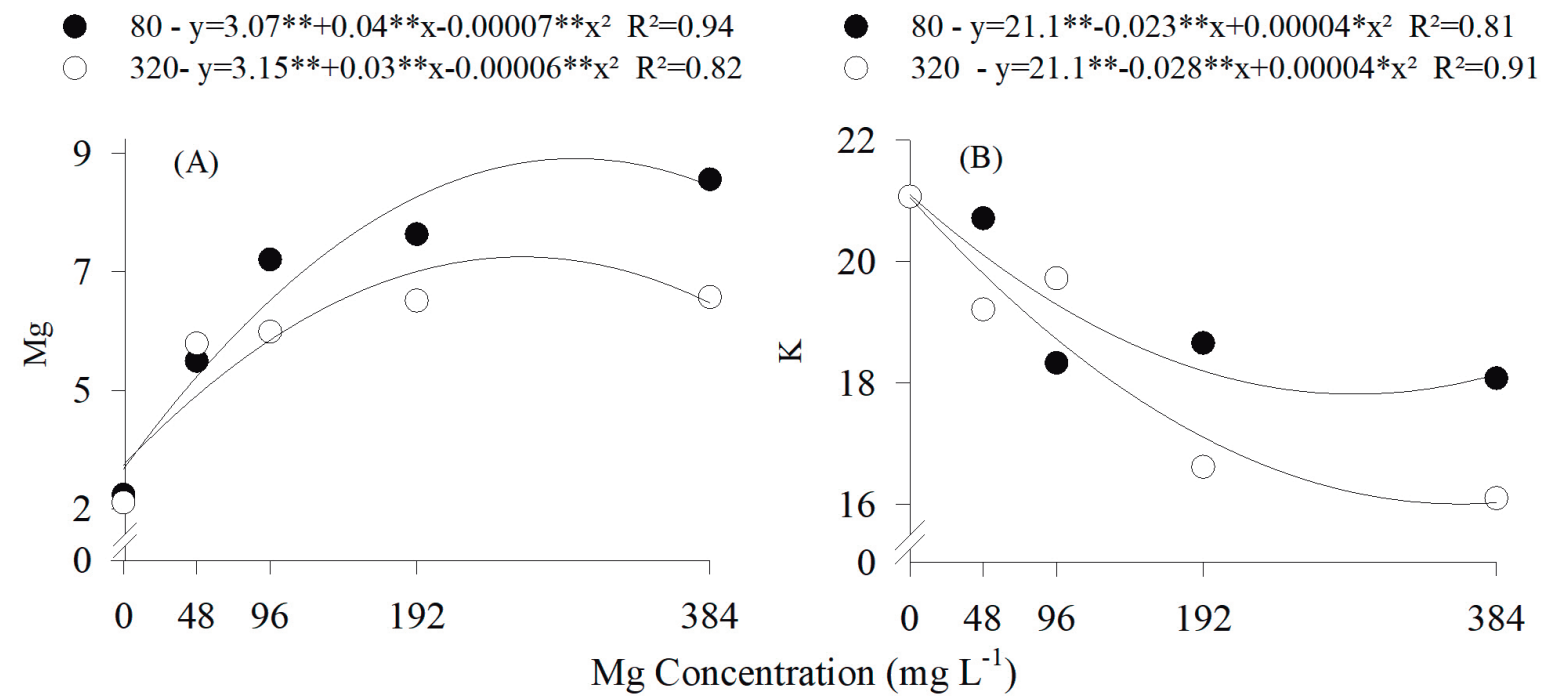

FIGURE 1 - Contents of Mg (a) and K (b) in leaves of coffee seedlings as a function of the application of different concentrations of $\mathrm{Mg}$ at two irradiance levels, 80 (closed circle) and 320 (empty circle) $\mu$ mol of photons $\mathrm{m}^{-2} \mathrm{~s}^{-1}$. Significance according to t-test is indicated at 5\% (*) and $1 \%(* *)$ 
$80-\mathrm{y}=3.27 * *-0.018 * * \mathrm{x}+0.000046 * * \mathrm{x}^{2} \quad \mathrm{R}^{2}=0.83$

○ $320-\mathrm{y}=3.3^{* *}-0.016^{* *} \mathrm{x}+0.000087^{* *} \mathrm{x}^{2} \quad \mathrm{R}^{2}=0.90$

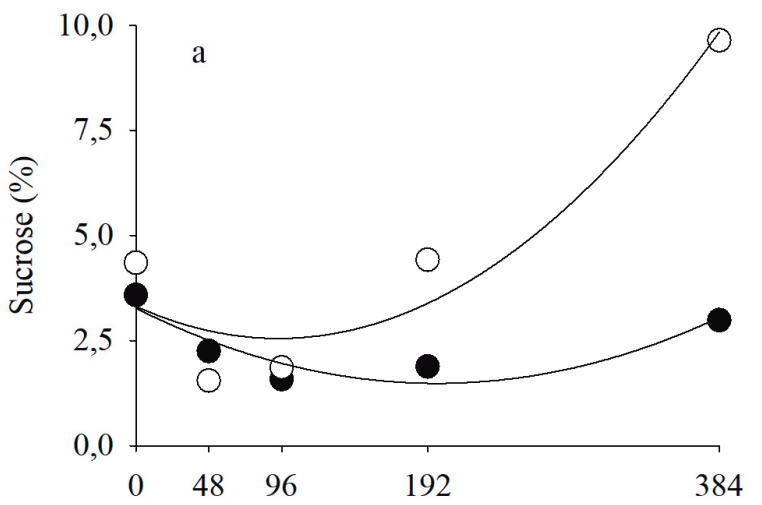

- $80-\mathrm{y}=0.44^{* *+0}+0003^{* *} \mathrm{x} \quad \mathrm{R}^{2}=0.88$

$320-\mathrm{y}=0.38^{* *+0}+0.0055^{* *} \mathrm{x} \quad \mathrm{R}^{2}=0.90$

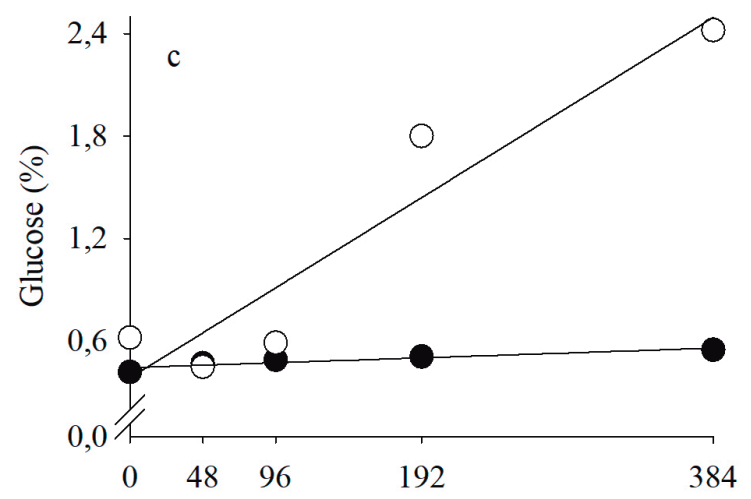

$80-\mathrm{y}=0.63 * *+0.0012 * * \mathrm{x} \quad \mathrm{R}^{2}=0.87$

$320-\mathrm{y}=0.59 * *+0.005 * * \mathrm{x} \quad \mathrm{R}^{2}=0.90$

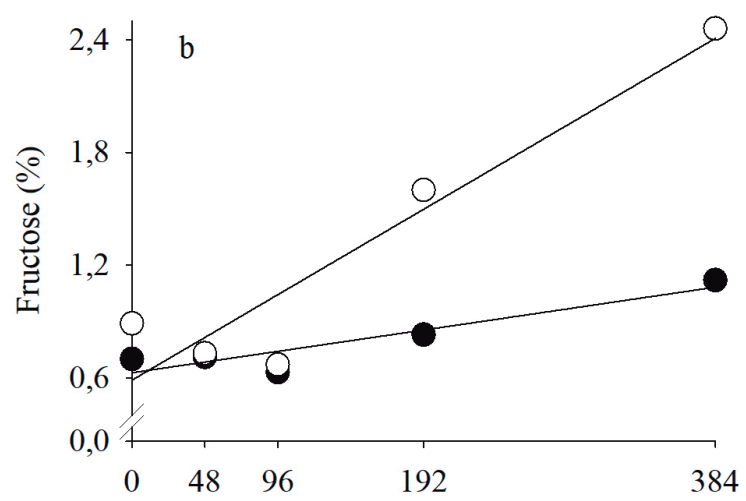

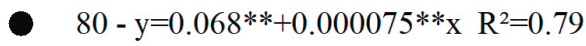

$320-\mathrm{y}=0.058 * *+0.0004 * * \mathrm{x} \quad \mathrm{R}^{2}=0.97$

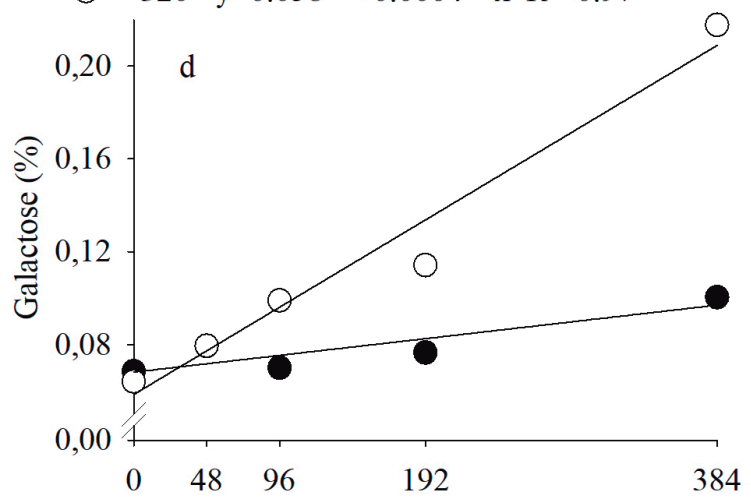

$80-\mathrm{y}=4.5 * *-0.018 * * \mathrm{x}+0.00005 * * \mathrm{x}^{2} \quad \mathrm{R}^{2}=0.84$

$320-\mathrm{y}=3.46^{*} 1.004 * *{ }^{\mathrm{X}} \mathrm{R}^{2}=0.88$

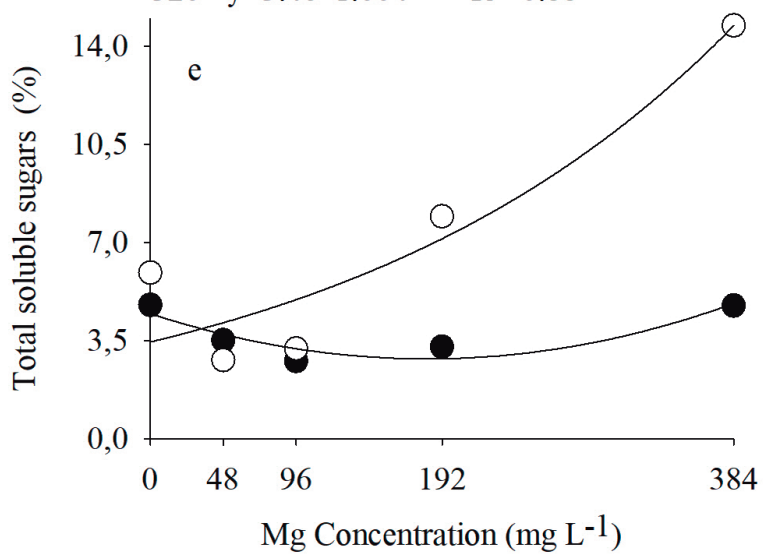

FIGURE 2 - Levels of (a) sucrose, (b) fructose, (c) glucose, (d) galactose, and (e) TSS in leaves of coffee seedlings as a function of the application of different concentrations of $\mathrm{Mg}$ at two irradiance levels $(80$ and $320 \mu \mathrm{mol}$ of photons $\left.\mathrm{m}^{-2} \mathrm{~s}^{-1}\right)$. Significance according to t-test is indicated at $5 \%(*)$ and $1 \%(* *)$. 
Thus, $\mathrm{Mg}$ has a direct effect on the transport of carbohydrates, especially sucrose, via the phloem (CAKMAK et al., 1994; CAKMAK; KIRKBY, 2008).

The function that $\mathrm{Mg}$ performs in the transport of carbohydrates could be relates to the decrease in the metabolic activity of the source organs (WARAICH, et al., 2011). However, it is most likely relates to the decrease in the Mg-ATP concentration in the transport locations of the phloem (CAKMAK; KIRKBY, 2008; HERMANS et al., 2010). Depending on the species that transport may occur actively and selectively (symplastic pathway), thus requiring energy in the form of ATP for co-transport via the plasma membrane $(\mathrm{H}+)$ (TAIZ; ZEIGER, 2009).

The increases in the sucrose levels from the previously mentioned concentrations are probably relates to the reduced absorption of $\mathrm{K}$ due to the excess $\mathrm{Mg}$ in the solution (figure 1). The higher sucrose accumulations were observe at the 320 $\mu \mathrm{mol}$ of photons $\mathrm{m}^{-2} \mathrm{~s}^{-1}$ of irradiance and the highest rate of photosynthesis was also relates to the lower $\mathrm{K}$ levels observed.

$\mathrm{K}$ deficiency causes a reduction in the transport and use of photoassimilates (MARSCHNER, 2012). Cakmak et al. (1994) observed higher concentrations of sucrose and reducing sugars in the leaves of bean plants deficient in $\mathrm{Mg}$ and $\mathrm{K}$. In addition to the accumulation of carbohydrates in the leaves, the role of $\mathrm{K}$ in the transport of carbohydrates is supported by the lower concentrations of sucrose in the roots of plants deficient in K compared with the roots of plants with adequate supply of this nutrient (CAKMAK et al., 1994). Therefore, $\mathrm{K}$ is required for the efficient transport of carbohydrates (sucrose particularly) via the phloem (PILOT et al., 2003).

In plants deficient in K, soluble carbohydrates and soluble nitrogen compounds accumulate, and the starch content decreases (MARTINEZ et al., 2014). These changes are related to the high requirement of $\mathrm{K}$ for the functioning of certain regulatory enzymes, in particular, pyruvate kinase and phosphofructokinase (MARSCHNER, 2012). According to Hermans et al. (2010) these reductions in photosynthesis rates observed in plants deficient in $\mathrm{K}$ may occur as a consequence of sucrose accumulation in the leaves due to their role in the synthesis and transport of carbohydrates. Moreover, K is extremely important in the activation of the carboxylase function of ribulose-1,5-bisphosphate carboxylase/oxygenase (Rubisco) (PRADO, 2008). Increases in photosynthetic rates due to the adequate supply of $\mathrm{K}$ have been attributed to these functions (CATUCHI et al., 2011; JIA et al., 2008;).
At the higher $\mathrm{Mg}$ concentrations, there was greater accumulation of sucrose (Figure 2a), fructose (Figure 2b), glucose (Figure 2c), galactose (Figure 2d), and TSS (Figure 2e), especially in the plants subjected to the higher irradiance level (320 $\mu \mathrm{mol}$ of photons $\mathrm{m}^{-2} \mathrm{~s}^{-1}$ ). This likely indicates that plants grown under high irradiance levels require a greater supply of $\mathrm{K}$ to maintain transport of carbohydrates via the phloem at normal rates.

Fructose and glucose (sucrose precursors) were present at higher levels than galactose. This behavior was linear for the fructose, glucose, and galactose contents at the two studied irradiance levels (Figures 2b, 2c, and 2d).

The levels of TSS resulting from the $\mathrm{Mg}$ concentrations behaved quadratically at the lower irradiance level and exponentially at $320 \mu \mathrm{mol}$ of photons $\mathrm{m}^{-2} \mathrm{~s}^{-1}$ of irradiance.

Seedlings in $0 \mathrm{mg} \mathrm{L}^{-1}$ of $\mathrm{Mg}$, showed higher contents of fructose (Figure 2b) and glucose (Figure 2c) at the highest irradiance level, and TSS (Figure 2e) increased at both irradiance levels. That indicates that $\mathrm{Mg}$ also plays a role in the transport of these sugars and/or in the sucrose transformation reactions. Silva et al. (2014) observed increases in the levels of sucrose, reducing sugars, and TSS as a function of $\mathrm{Mg}$ deficiency in coffee seedlings; however, the effect of excess $\mathrm{Mg}$ on the levels of reducing sugars (fructose, glucose, and galactose) - see Figures $2 b, 2 c$, and $2 d-$ was more significant. Perhaps $\mathrm{K}$ has a more important role in the transport and/ or transformation of these sugars. The synthesis of carbohydrates is dependent on sucrose-cleaving enzymes, sucrose synthase (SuSy), and invertases, which also influence the velocity of transport in the phloem in the source/drain direction - some of these enzymes are activated by K (TAIZ; ZEIGER, 2009).

In general, there was a greater accumulation of carbohydrates at the extremes of Mg supply ( 0 and $384 \mathrm{mg} \mathrm{L}^{-1}$ ), at the highest irradiance level, due to the higher photosynthesis rate probably (Dias 2015).

\subsection{Relative distribution of carbohydrates}

The $\mathrm{Mg}$ concentrations also altered the relative distribution of carbohydrates in the coffee leaves; that is, the ratio of the content of each carbohydrate relative to the total soluble sugar (TSS) - see Figure 3 - fit a decreasing quadratic function for the sucrose and increasing quadratic for the reducing sugars. 


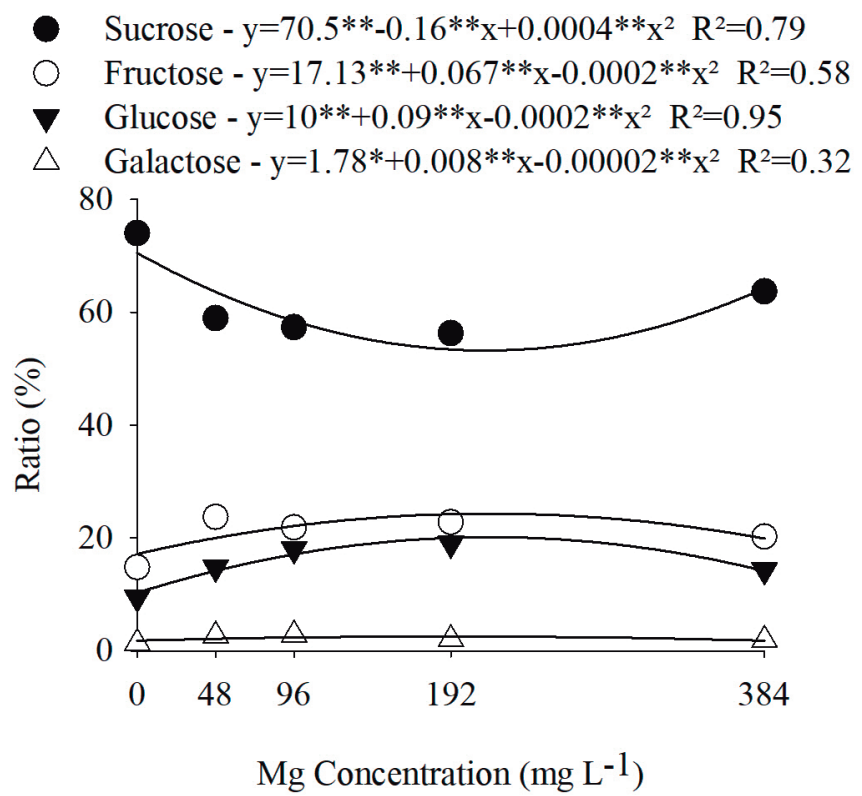

FIGURE 3 - Relative distribution of carbohydrates in leaves of coffee seedlings as a function of the application of different concentrations of $\mathrm{Mg}$ and two irradiance levels. Significance according to t-tests is indicated at $5 \%(*)$ and $1 \%(* *)$

The highest percentage of sucrose in relation to the other sugars was observed in the control, indicating that $\mathrm{Mg}$ deficiency has more influence on the accumulation of sucrose proportionally.

Regardless of the Mg concentration, sucrose was the sugar with the highest concentration in the leaves, followed by fructose, glucose, and then galactose, which had values below the others. According to Ding and $\mathrm{Xu}$ (2011) sucrose and starch are the main photosynthetic products in almost all of the higher plants.

Irradiance levels had no effect on the relative distribution of carbohydrates. On the other hand, there were changes in the carbohydrate content ratios with the different $\mathrm{Mg}$ concentrations. The proportions of sucrose: fructose: glucose: galactose were 74: 15: 10: $1 \%$ with $0 \mathrm{~g} \mathrm{~L}^{-1}$ of $\mathrm{Mg}$ to the plants. A supply of $48 \mathrm{~g} \mathrm{~L}^{-1}$ of $\mathrm{Mg}$ resulted in 59: 24: $15: 3 \%$ of sucrose, fructose, glucose and galactose, while $96 \mathrm{~g} \mathrm{~L}^{-1}$ of $\mathrm{Mg}$ resulted in 57: 22: 18: $3 \%$, respectively. The concentration of $192 \mathrm{~g}$ $\mathrm{L}^{-1}$ of $\mathrm{Mg}$ resulted in 56: 23: 19: $2 \%$ of sucrose, fructose, glucose and galactose and of $384 \mathrm{~g} \mathrm{~L}^{-1}$ of $\mathrm{Mg}$ in 64: 20: 14: 2\% sucrose, fructose, glucose and galactose.

Sucrose has a fundamental role in plant metabolism, acting as a source of carbon and energy, especially for non-photosynthetic tissues (BASSON et al., 2010). Reduction in the sucrose synthesis rate or increase in its degradation affects plant physiology, root development, and fruit quality (KÜHN; GROF, 2010).
The main enzymes that catalyze the sucrose dynamics reactions are sucrose synthase (SuSy), sucrose phosphate synthase (SPS), and the invertases (alkaline invertase and acid invertase). SPS controls the biosynthesis and accumulation of sucrose and it plays an important role in the translocation and distribution of photoassimilates in higher plants (TAIZ; ZEIGER, 2009; WANG et al., 2013). SuSy and alkaline invertase are primarily located in the cytosol, where as acid invertase is mainly associated with cell walls and vacuoles, where $\mathrm{pH}$ is approximately 5 (TAIZ; ZEIGER, 2009).

The catalyzed equations are:

Sucrose synthase: Sucrose $+U D P \longleftrightarrow$ Fructose $+U D P-G l u c o s e$

Sucrose phosphate synthase: Sucrose $+U D P \longleftrightarrow$ Fructose $+U D P G$

Invertase: Sucrose $+\mathrm{H}_{2} \mathrm{O} \longrightarrow$ Fructose + Glucose

In addition to the reactions shown, SPS could also irreversibly convert sucrose-6-phosphate into sucrose (PARK et al., 2009).

The importance of these enzymes depends on where sucrose is being metabolizes. SuSy is likely the main enzyme that degrades sucrose in organs that store starch (e.g., developing seeds or tubers) and in tissues undergoing rapid growth, which require translocated sucrose in the respiration process for the production of energy and 
carbon skeletons. However, when the unloading of the phloem occurs passively (via apoplast), the acid invertase - because it is present in the cell wall - can convert the sucrose into hexoses (fructose and glucose) before entering the cell. In mature cells, cytosolic invertase may be important in the degradation of sucrose, supplying glucose and fructose for respiration (HOPKINS, 2000).

SPS is a key enzyme in the carbohydrate dynamics of plants - it is primarily responsible for the participation of sucrose in the physiological processes of different metabolisms. Previous studies of different crops have found a correlation between sucrose accumulation and increases in SPS activity or decreases in invertase activity (HIROTSU et al., 2007; ISHIMARU et al., 2008; ZHANG et al., 2010).

The relationships between sucrose and fructose and between sucrose and glucose were inversely proportional, suggesting that $\mathrm{Mg}$ and/or $\mathrm{K}$ participate in the activities of these enzymes. $\mathrm{K}$ has an established connection to SuSy activity (TAIZ; ZEIGER, 2009). Mg is possibly relates to invertase activity because the activity of these enzymes is generally inversely proportional to sucrose accumulation. However, more research is required regarding the role of these nutrients in the activity of these enzymes.

\subsection{Antioxidant metabolism}

The increase in $\mathrm{Mg}$ concentrations in the solution decreased the enzyme activity of the plant antioxidant system (SOD, CAT, and APX) - see Figures 4 and 5. For the SOD activity, the interaction between the $\mathrm{Mg}$ concentrations and the irradiance was not significant - the activity of this enzyme as a function of the concentrations was represent by a decreasing quadratic function (Figure 4). Increasing $\mathrm{Mg}$ concentrations up to $245 \mathrm{mg} \mathrm{L}^{-1}$ caused a reduction in SOD activity, and from this point onward, the activity of this enzyme increased. SOD is responsible for the dismutation of $\mathrm{O}_{2}$ to form $\mathrm{H}_{2} \mathrm{O}_{2}$ and $\mathrm{O}_{2}$ and it is consider the first line of defense against ROS (KARUPPANAPANDIAN et al., 2011). CAT and APX are enzymes that catalyze the conversion of $\mathrm{H}_{2} \mathrm{O}_{2}$ to water and $\mathrm{O}_{2}$ (ABEDI et al., 2010).

Increases in the activity of the antioxidant system resulting from $\mathrm{Mg}$ deficiency have been observed in the following crops: rice (CHOU et al., 2011), bean (CAKMAK; YAZICI, 2010), and coffee (SILVA et al., 2014).

Silva et al. (2014) observed the greater activity of the SOD, CAT, and APX enzymes in coffee seedlings deficient in Mg compared with those with an adequate supply of $\mathrm{Mg}$.
Before the appearance of visual $\mathrm{Mg}$ deficiency symptoms, the activity of the enzymes from the antioxidant complex of the plant reduces the photooxidative damage caused by ROS and the inactivation of photosynthetic enzymes, which results in decreased photosynthetic activity only at more advanced stages of deficiency (KAISER, 1976).

The interaction between the $\mathrm{Mg}$ concentrations and the irradiance levels was significant for both APX and CAT activities. The activity of these enzymes as result of the $\mathrm{Mg}$ concentrations fit a descending quadratic function within each irradiance level, for both the growth chamber samples and the samples exposed to full sunlight (Figure 5). The significant interaction indicates that the activity of these enzymes as a function of the $\mathrm{Mg}$ concentrations depends on the irradiance.

The CAT and APX activities were both greater at lower $\mathrm{Mg}$ concentrations. According to Cakmak and Yazici (2010), high levels of components from the antioxidant metabolism are a physiological response of the plants to the effects of $\mathrm{Mg}$ deficiency.

The activation of antioxidant metabolism, under $\mathrm{Mg}$ deficiency, likely occurs in chloroplasts, the location of a reduction in $\mathrm{O}_{2}^{-}$and $\mathrm{H}_{2} \mathrm{O}_{2}$ as a result of the restricted consumption of reducing potential in the fixation of $\mathrm{CO}_{2}^{-}$(Silva et al., 2014).

Excessive $\mathrm{Mg}$ also caused an increase in the enzyme activity of the antioxidant system (Figures 3 and 4) likely due to the physiological disorders caused by the excess of this nutrient itself, the reduction in the absorption of other nutrients, especially $K$, and the increase in the saline concentration of the solution.

Several studies have demonstrated the role of enzymatic antioxidant mechanisms in protecting against oxidative stress induced by salinity (RUBIO et al., 2009). The increase in the activity of enzymes such as SOD, APX, and CAT is associated with maintaining levels of lipid peroxidation under salt stress (ASHRAF, 2009).

$\mathrm{K}$ deficiency can increase the production of ROS in conditions of environmental stress particularly, for example, drought, high light intensity, heat, and nutrient limitation, and the improvement in potassium nutrition could greatly reduce the production of ROS through the reduction of NADPH oxidase activity and the maintenance of electron transport (Cakmak et al., 1994). K deficiency causes a reduction in the photosynthetic fixation of $\mathrm{CO}_{2}$ and losses in the transport and use of photoassimilates. Such disorders can result in an excess of electrons, thereby stimulating the production of ROS (MARSCHNER, 2012). 


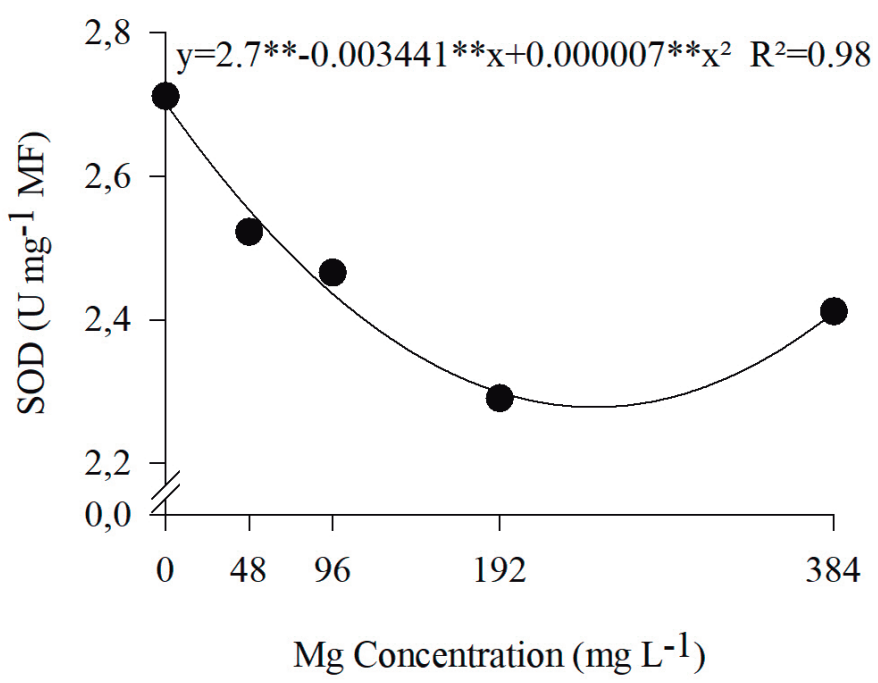

FIGURE 4 - Activity of the superoxide dismutase (SOD) enzyme resulting from the application of different concentrations of $\mathrm{Mg}$. Significance according to t-tests indicated at $5 \%\left(^{*}\right)$ and $1 \%(* *)$.

$80-\mathrm{y}=4.02 * *-0.011 * * \mathrm{x}+0.00002 * * \mathrm{x}^{2} \quad \mathrm{R}^{2}=0.89$

8 $80 / 1500-\mathrm{y}=5.03 * *_{-}-0.036 * *^{\mathrm{x}}+0.00009 * \mathrm{x}^{2} \quad \mathrm{R}^{2}=0.90$

V $320-\mathrm{y}=4.8 * *-0.015 * * \mathrm{x}+0.000026 * * \mathrm{x}^{2} \quad \mathrm{R}^{2}=0.98$

$\triangle 320 / 1500-\mathrm{y}=3.9 * *-0.013 * *+0.00002 * * \mathrm{x}^{2} \quad \mathrm{R}^{2}=0.88$

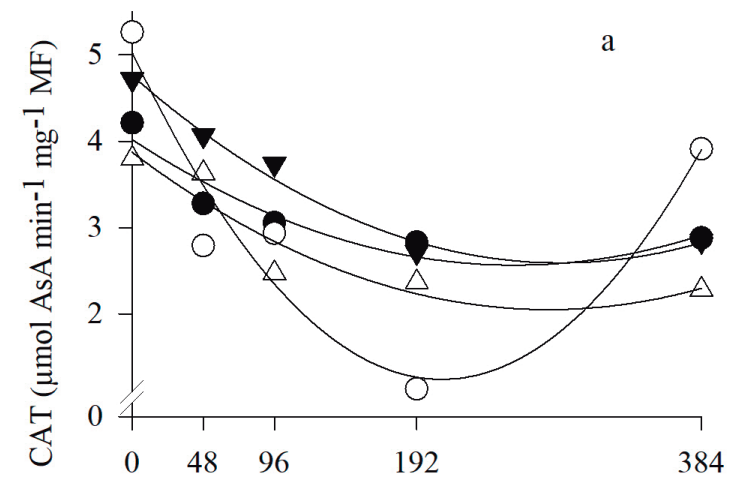

$80-\mathrm{y}=15.3 * *-0.03 * \mathrm{x}+0.00006 * \mathrm{x}^{2} \quad \mathrm{R}^{2}=0.95$

O $80 / 1500-\mathrm{y}=21.8 * *-0.13 * * \mathrm{x}+0.0003 * * \mathrm{x}^{2} \quad \mathrm{R}^{2}=0.97$

V $320-\mathrm{y}=21.8 * *-0.089 * * \mathrm{x}+0.0002 * *_{\mathrm{x}}{ }^{2} \quad \mathrm{R}^{2}=0.92$

$\triangle 320 / 1500-\mathrm{y}=20.5 * *-0.08 * * \mathrm{x}+0.0002 * * \mathrm{x}^{2} \quad \mathrm{R}^{2}=0.83$

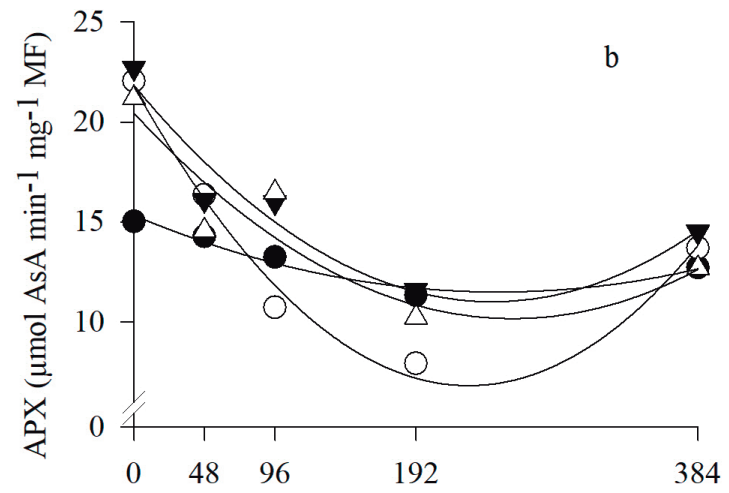

$\mathrm{Mg}$ Concentration $\left(\mathrm{mg} \mathrm{L}^{-1}\right.$ )

FIGURE 5 - Activity of (a) CAT and (b) APX enzymes in coffee seedlings as a function of the application of different concentrations of $\mathrm{Mg}$ and different irradiance levels in samples collected inside and outside the growth chamber after full sun exposure (/1500). Significance according to t-test is indicated at 5\%(*) and $1 \%(* *)$

In addition to the Mg content, light intensity also influences biochemical and physiological processes in which $\mathrm{Mg}$ is involved, causing visual symptoms typical of deficiency, the reduction of the transport of carbohydrates, root growth (CAKMAK; KIRKBY, 2008) and reductions in crop productivity consequently.

The saturation irradiances of photosynthesis in coffee trees are relatively low (300 to $700 \mu \mathrm{mol}$ of photons $\mathrm{m}^{-2} \mathrm{~s}^{-1}$ ) (DAMATTA et al., 2004). Irradiances higher than those needed to saturate the photosynthetic complex can cause photoinhibition of photosynthesis. Additionally, they often lead to decreases in the rate of electron transport through photosystem II (PSII) and to increases in the spin rate of $\mathrm{D} 1$, the main polypeptide of the PSII reaction centers (NISHIYAMA,et al., 2011). 
In general, during sampling within the chamber where the irradiance was controlled, the highest irradiance level $\left(320 \mu \mathrm{mol}\right.$ of photons $\left.\mathrm{m}^{-2} \mathrm{~s}^{-1}\right)$ triggered greater CAT and APX activities at $0 \mathrm{mg}$ $\mathrm{L}^{-1}$ of $\mathrm{Mg}$. With increasing $\mathrm{Mg}$ concentrations, the activity of these enzymes at the higher (320 $\mu \mathrm{mol}$ of photons $\left.\mathrm{m}^{-2} \mathrm{~s}^{-1}\right)$ and lower $(80 \mu \mathrm{mol}$ of photons $\mathrm{m}^{-2} \mathrm{~s}^{-1}$ ) irradiance levels tended to be equal (Figure 4). The effect of irradiance antioxidants enzyme activity became even more evident in the plants in the lower irradiance $(80 \mu \mathrm{mol}$ of photons $\mathrm{m}^{-2} \mathrm{~s}^{-1}$ ) that were exposed to full sun, where the irradiance reached $1500 \mu \mathrm{mol}$ of photons $\mathrm{m}^{-2} \mathrm{~s}^{-1}$. This change in irradiance expose caused stress, which increased the CAT and APX activities of the control; however, less activity occurred due to the increase in the $\mathrm{Mg}$ concentrations.

Cakmak and Yazici (2010) observed a rapid increase in the antioxidant mechanisms in bean plants with $\mathrm{Mg}$ deficiency, especially those exposed to high light intensities.

Increases in the formation of ROS occur when the absorption of light energy captured by the plant exceeds the utilization capacity during photosynthesis (Murchie and Niyogi, 2011). These excess ROS are toxic to the cells and destroy chlorophyll, the membranes, DNA, and other organelles. Under normal growth conditions, the accumulation of ROS in cells is low. However, adverse environmental factors that disturb cellular homeostasis induce the production of ROS, thus leading to oxidative stress (MILLER, et al., 2010).

Additionally, even for the control, the coffee seedlings did not display the typical visual symptoms of deficiency in the growth chamber. After being exposes to full sun for three days, the typical visual symptoms of deficiency appeared, together with symptoms of scald, which appeared more intensely in the control plant and at the highest concentration of $\mathrm{Mg}$ due to the restriction in the absorption of $\mathrm{K}$.

The oldest part of the leaf, which was shade by the younger leaf, remained green, whereas the portion that was exposes to full irradiance exhibited symptoms of scald (Figure 6). Note also that the newest leaf that was fully expose to irradiance, even with less physical protection, remained green (Figures 6 and 7). This occurred because the scald is the effect of photooxidative damage and is not a purely physical process. $\mathrm{Mg}$ and $\mathrm{K}$, which are mobile in the plant, most likely have an important role in protecting newer leaves against scald.
At high light intensities, the development of chlorosis increases, together with some reddish spots on the leaf blade, and the parts of the leaves that did not receive the full luminosity were asymptomatic (Cakmak and Kirkby, 2008). Plants growing in high-intensity light conditions appear to have higher $\mathrm{Mg}$ demands than plants grown under low light intensity.

The increased oxidative stress observed as a function of the $\mathrm{Mg}$ deficiency, which was more evident in the plants exposed to higher irradiance levels, can be link to several factors:

-With the onset of the stress caused by $\mathrm{Mg}$ deficiency, carbohydrates accumulated in the leaves (Figure 1), as has been previously observed by several authors (CAKMAK et al., 1994; SILVA et al., 2014). This accumulation of carbohydrates changes the photosynthetic metabolism and reduces the use of the light energy absorbed in photosynthesis, leading to a saturation of the electron transport chain with the accumulation of NADPH (HERMANS et al., 2010). High levels of reducing equivalents and components of the saturated electron chain offer favorable conditions for the formation of ROS (BIEMELT et al., 1998; MITTLER, 2002).

-Mg also affects the activity of Rubisco, and the binding of this enzyme to $\mathrm{Mg}$ increases the affinity for $\mathrm{CO}_{2}$ and doubles the maximum reaction velocity (SUGIYAMA et al., 1968). Therefore, under $\mathrm{Mg}$ deficiency, the photosynthetic rate will decrease, thereby generating the accumulation of oxygen and reducing equivalents, which leads to the generation of ROS and, consequently, triggers oxidative stress. This process is more serious in high irradiance conditions because the generation of reducing equivalents and water absorption are both higher.

The results demonstrated that a relationship exists between the antioxidant complex of the coffee tree and the Mg supply as a function of the irradiance to which the plants are subject. $\mathrm{Mg}$ appears to work as a mitigating agent of oxidative stress under stress conditions caused by increased irradiance.

The results indicate the need for regional field studies, given that coffee is cultivated in various regions of Brazil and other countries with different irradiance levels, and thus, the requirements for $\mathrm{Mg}$ should not be the same for these different conditions. 


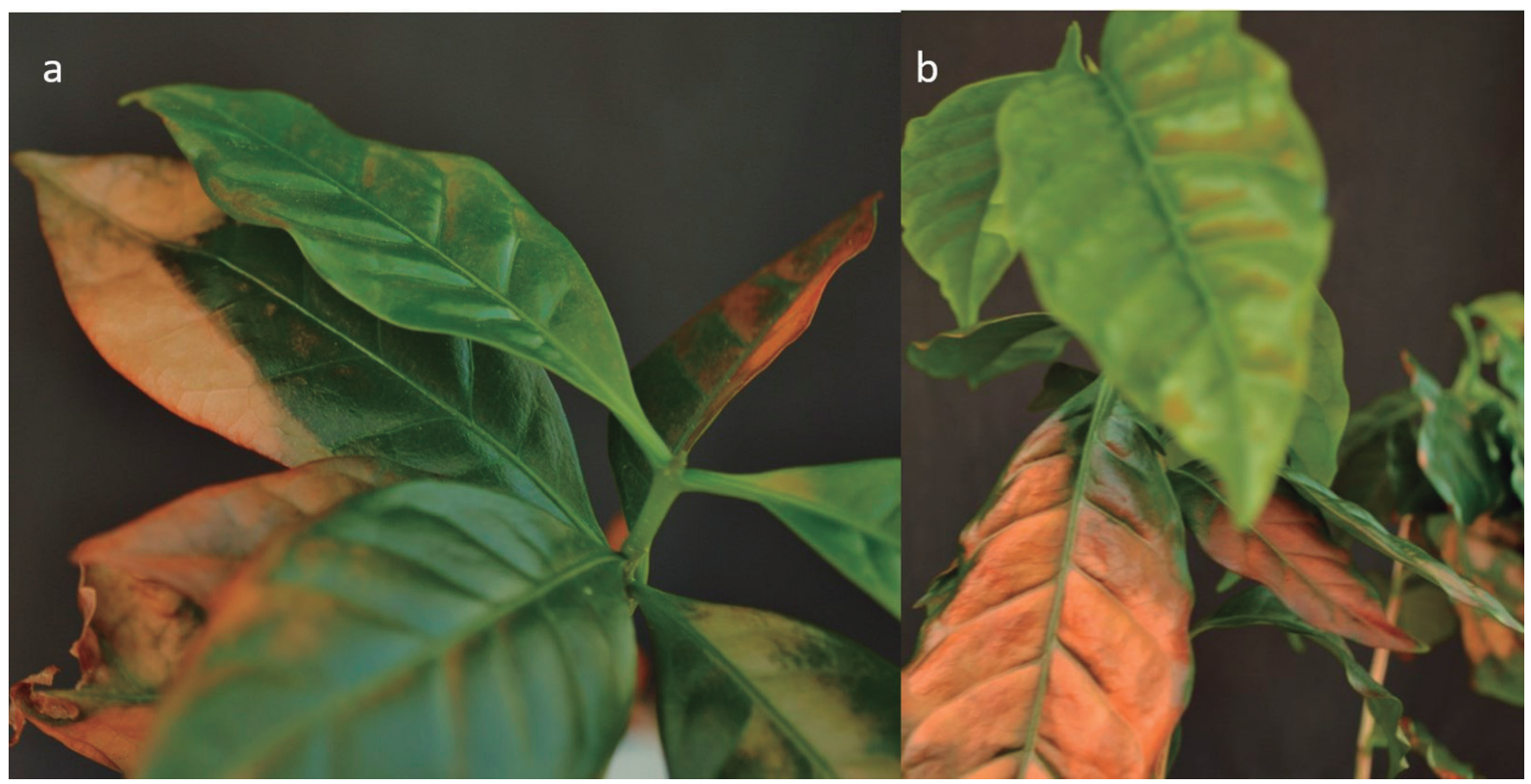

FIGURE 6 - Coffee seedlings cultivated in nutrient solution with no Mg supplied and exposed to full sun for three days.

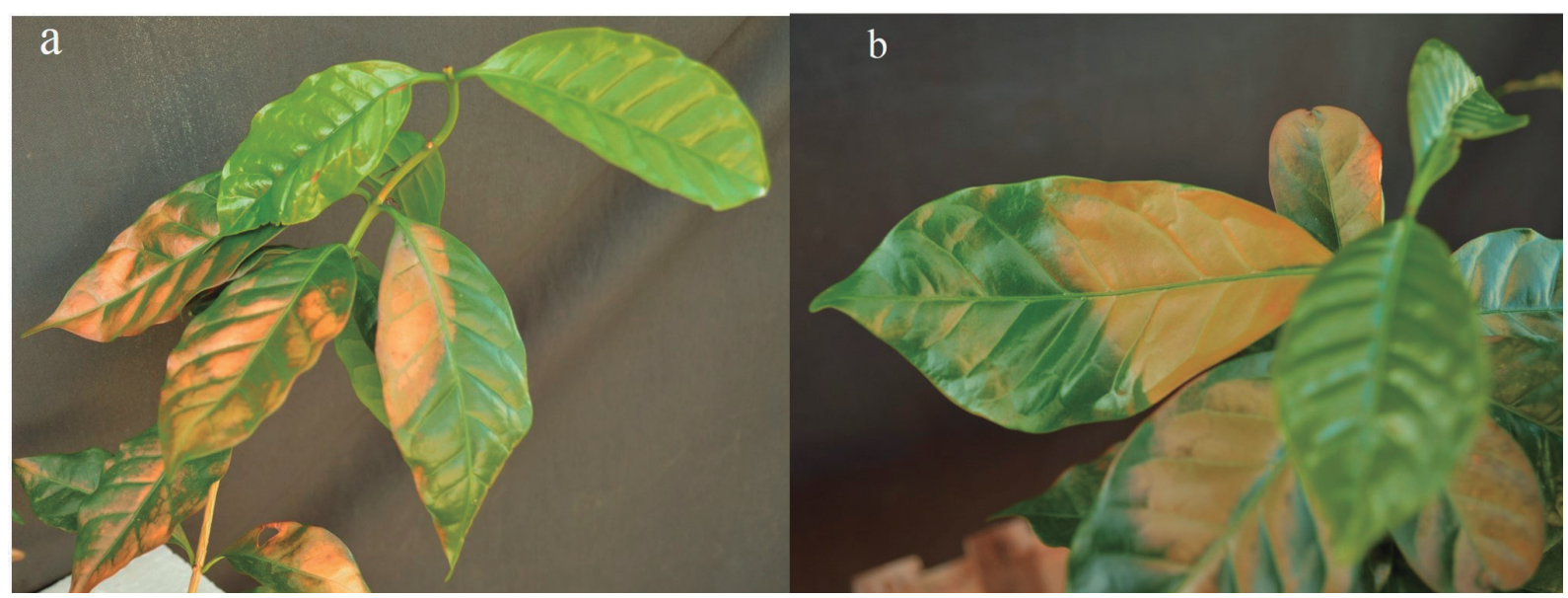

FIGURE 7 - Coffee seedlings cultivated in nutrient solution with a high level of Mg supplied (low foliar content of $\mathrm{K}$ ) and exposed to full sun for three days.

\section{CONCLUSIONS}

Available Mg levels influence the carbohydrate dynamics in the leaves of coffee trees. Both the deficiency and excess of $\mathrm{Mg}$ cause increases in their carbohydrate content, especially sucrose in the coffee leaves. Coffee seedlings leaves are highest in sucrose content, followed by fructose and glucose, which are in turn greater than the amount of galactose present in the leaves.

The accumulation of carbohydrates in coffee tree leaves is dependent on the irradiance to which the plants are subject. Under conditions of deficiency or excess of $\mathrm{Mg}$, leaves exposed to higher irradiances accumulate more carbohydrates.

The accumulation of carbohydrates in coffee tree leaves caused increases in antioxidant enzyme activity due to the greater production of ROS.

Deficiency or excess of $\mathrm{Mg}$ under high radiation conditions leads to intense photooxidation and symptoms of sun scalding in the coffee leaves.

There is a close relationship between the antioxidant complex of coffee trees and the $\mathrm{Mg}$ supply due to the irradiance to which the plants are subject where $\mathrm{Mg}$ acts as a mitigating agent of oxidative stress caused by increased irradiance. 


\section{REFERENCES}

ABEDI, T. et al. Antioxidant enzyme changes in response to drought stress in ten cultivars of oilseed rape (Brassica napus L.). Czech Journal of Genetics and Plant Breeding, Prague, v. 46, n. 1, p. 27-34, Jan/ Mar. 2010.

ASHRAF, M. Biotechnological approach of improving plant salt tolerance using antioxidants as markers. Biotechnology advances, v. 27 , n. 1, p. 8493, Jan/Feb. 2009.

BASSON, C. E. et al. Sugar and acid-related quality attributes and enzyme activities in strawberry fruits: invertase is the main sucrose hydrolysing enzyme. Food Chemistry, London, v. 121, n. 4, p. 1156-1162, Aug. 2010.

BIEMELT, S.; KEETMAN, U.; ALBRECHT, G. Reaeration following hypoxia or anoxia leads to activation of the antioxidative defense system in roots of wheat seedlings. Plant Physiology, Washington, v. 116, n. 2, p. 651-658, Feb. 1998.

CAKMAK, I.; HENGELER, C.; MARSCHENER, $H$. Changes in phloem export of sucrose in leaves in response to phosphorus, potassium and magnesium deficiency in bean plants. Journal of Expert Botany, London, v. 45, n. 9, p. 1251-1257, Sept. 1994.

CAKMAK, I.; KIRKBY, E. A. Role of magnesium in carbon partitioning and alleviating photooxidative damage. Physiologia Plantarum, Copenhagen, v. 133, n. 4, p. 692-704, Aug. 2008.

CAKMAK, I.; YAZICI, A.M. Magnesium: a forgotten elemento in croop production. Better Crops with Plant Food, Norcross, v. 94, n. 2, p. 23-25, 2010.

CATUCHI, T. A. et al. Tolerance to water deficiency between two soybean cultivars: transgenic versus conventional. Ciência Rural, v. 41, n. 3, p. 373-378, Mar. 2011.

CHOU, T. S. et al. Effect os magnesium deficiency on antioxidante status and cádmium toxicity in rice seedlings. Journal of Plant Physiology, New York, v. 168, n. 10, p. 1021-1030, July 2011.

DAMATTA, F. M. et al. Ecophysiological constraints on the production of shaded and unshaded coffee: a review. Field Crops Research, Amsterdam, v. 86, n. 2, p. 99-114, Mar. 2004.
DIAS, K. G. L. Nutrição, bioquímica e fisiologia de cafeeiros supridos com magnésio. 2015. 80 p. Tese (Doutorado em Solos) - Universidade Federal de Lavras, Lavras, 2015.

DING, Y.; XU, G. Low magnesium with high potassium supply changes sugar partitioning and root growth pattern prior to visible magnesium deficiency in leaves of Rice (Oryza sativa L.). American Journal of Plant Sciences, Amsterdam, v. 2, n. 4, p. 601-608, Oct. 2011.

EMPRESA BRASILEIRA DE PESQUISA AGROPECUÁRIA. Manual de analises químicas de solos, plantas e fertilizantes. 2. ed. Brasília: Embrapa Informação Tecnológica, 2009.

FERREIRA, D. F. SISVAR: a computer statistical analysis system. Ciência e Agrotecnologia, Lavras, v. 35, n. 6, p. 1039-1042, Nov/Dec. 2011.

GILL, S. S, TUTEJA, N. Reactive oxygen species and antioxidant machinery in abiotic stress tolerance in crop plants. Plant Physiology and Biochemistry, v. 48, n. 12 p. 909-930, Dec. 2010.

HAVIR, E. A.; MCHALE, N. A. Biochemical and developmental characterization of multiple forms of catalase in tobacco leaves. Plant Physiology, Washington, v. 84, n. 2, p. 450-455, June. 1987.

HERMANS, C. et al. Systems analysis of the responses to long term magnesium deficiency and restoration in Arabidopsis thaliana. New Phytologist, v. 187, n. 1, p. 132-144, July. 2010.

HIROTSU, N.; KASHIWAGI T.; MADOKA, Y. Strategies to improve plant height for the production of biomass energy in rice. Japanese Journal of Crop Science, Tokyo, v. 76, n. 4, p. 501-507, Oct/Dec. 2007.

HOAGLAND, D.; ARNON, D. I. The water culture method for growing plants without soil. Berkeley, Califórnia Agricultural Experiment Station, v. 347, n. 2ed. 1950.32 p.

HOPKINS, W. G. Introduction to plant physiology. 2nd ed. New York: John Wiley \& Sons, 2000.

HUSSAIN, S. S. et al. Polyamines: natural and engineered abiotic and biotic stress tolerance in plants. Biotechnology advances, v. 29, n. 3, p. 300311, May/June. 2011. 
ISHIMARU, K.; HIROTSU, N.; KASHIWAGI, T. Over-expression of a maize SPS gene improves yield characters of potato under field conditions. Plant Production Science, Oxford, v. 11, n. 1, p. 104-107, Jan. 2008.

JIA, Y. et al. Effects of potassium deficiency on chloroplast ultrastructure and chlorophyll fluorescence in inefficient and efficient genotypes of rice. Journal of Plant Nutrition, v. 31, n. 12, p. 2105-2118, Nov. 2008.

KAISER, M. W. The effect of hydrogen peroxide on $\mathrm{CO} 2$ fixation of isolated chloroplast. Biochimica Biophysica Acta, Amsterdam, v. 440, n. 3, p. 476-482, Sept. 1976.

KARUPPANAPANDIAN, T. et al. Reactive oxygen species in plants: their generation, signal transduction, and scavenging mechanisms. Australian Journal of Crop Science, v. 5, n. 6, p. 709-725, June. 2011.

KÜHN, C.; GROF, C. P. Sucrose transporters of higher plants. Current Opinion in Plant Biology, Amsterdam, v. 13, n. 3, p. 288-298, June. 2010.

MAROUANE, W. et al. The protective effect of Malva sylvestris on rat kidney damaged by vanadium. Lipids in health and disease, v. 10, n. 1, p. 65, Aug. 2011.

MARSCHNER, H. Mineral nutrition of higher plants. 3. ed. London: Academic Press, 2012.

MARTINEZ, H. E. P. et al. Nutrição mineral do cafeeiro e qualidade da bebida. Revista Ceres, Viçosa, v. 61, n. suppl, p. 838-848, Nov/Dec. 2014.

MARTINS, M. C. M. et al. Carboidratos na bebida do café preparado sob diferentes processos. Ciência e Tecnologia de Alimentos, Campinas, v. 25, n. 2, p. 382-386, Apr/June. 2005.

MELLINGER, C. G. Caracterização estrutural e atividade biológica de carboidratos de Phyllanthus niruri (quebra-pedra). 2006. 138 p. Tese (Doutorado em Ciências) - Universidade Federal do Paraná, Curitiba, 2006.

MILLER, G. A. D. et al. Reactive oxygen species homeostasis and signalling during drought and salinity stresses. Plant, cell \& environment, v. 33, n. 4, p. 453467, Apr. 2010.

MITTLER, R. Oxidative stress, antioxidants and stress tolerance. Trends Plant Science, Oxford, v. 7, n. 9, p. 405-410, Sept. 2002.
MURCHIE, E. H.; NIYOGI, K. K. Manipulation of photoprotection to improve plant photosynthesis. Plant physiology, v. 155, n. 1, p. 86-92, Jan. 2011.

NAKANO, Y.; ASADA, K. Hydrogen peroxide is scavenged by ascorbato-specific peroxidase in spinach chloroplasts. Plant and Cell Physiology, Kyoto, v. 22, n. 5, p. 867-880, Aug/Sept. 1981.

NEILL, S. et al. Nitric oxide, stomatal closure, and abiotic stress. Journal of Experimental Botany, Oxford, v. 59, n. 2, p. 165-176, Feb. 2008.

NISHIYAMA, Y. et al. Protein synthesis is the primary target of reactive oxygen species in the photoinhibition of photosystem II. Physiologia Plantarum, v. 142, n. 1, p. 35-46, May. 2011.

PARK, J. Y. et al. Sucrose phosphate synthase expression influences poplar phenology. Tree Physiology, v. 29, n. 7, p. 937-946, July. 2009.

PILOT, G. et al. Regulated expression of Arabidopsis Shaker $\mathrm{K}+$ channel genes involved in $\mathrm{K}+$ uptake and distribution in the plant. Plant Molecular Biology, Dordrecht, v. 51, n. 5, p. 773-787, Mar. 2003.

PRADO, R. M. Nutrição de plantas. São Paulo: Editora da Unesp, 2008. 408 p.

RUBIO, M. C. et al. Effects of salt stress on the expression of antioxidant genes and proteins in the model legume Lotus japonicus. New Phytologist, Cambridge, v. 181, n. 4, p. 851-859, Mar. 2009.

SÁNCHEZ-RODRÍGUEZ, E. et al. Genotypic differences in some physiological parameters symptomatic for oxidative stress under moderate drought in tomato plants. Plant science, v. 178, n. 1, p. 30-40, Jan. 2010.

SILVA, D. M. et al. Physiological and biochemical impacts of magnesium-deficiency in two cultivars of coffee. Plant and Soil, The Hague, v. 382, n. 1-2, p. 133-150, Sept. 2014.

SUGIYAMA, T.; NAKYAMA, N.; AKASAWA, T. Structure and function of chloroplast proteins. V. Homotropic effect of bicarbonate in RuBP carboxylase relation and the mechanism of activation by magnesium ions. Archives of Biochemistry and Biophysics, New York, v. 126, n. 3, p. 734-745, Sept. 1968.

TAIZ, L.; ZEIGER, E. Fisiologia vegetal. 4. ed. Porto Alegre: Artmed, 2009. 
WANG, L. et al. Research advance of sucrose phosphate synthase (SPS) in higher plant. International Journal of Agriculture \& Biology, Faisalabad, v. 15, n. 6, p. 1221-1226, June. 2013.

WARAICH, E. A. et al. Role of mineral nutrition in alleviation of drought stress in plants. Australian Journal of Crop Science, v. 5, n. 6, p. 764-777, June. 2011.
ZANANDREA, I. et al. Tolerance of Sesbania virgata plants to flooding. Australian Journal of Botany, v. 57, n. 8, p. 661-669, Nov/Dec. 2009.

ZHANG, X. M. et al. Cloning and expression of pineapple sucrose phosphate synthase gene during fruit development. African Journal of Biotechnology, Bowie, v. 9, n. 49, p. 8296-8303, Dec. 2010. 